\title{
ANALYSIS OF NITROGEN REMOVAL PERFORMANCE OF CONSTRUCTED RAPID INFILTRATION SYSTEM (CRIS)
}

\author{
XU, W. L. -ZHANG, W. ${ }^{*}$ - JIAN, Y. - WANG, J. - TANG, M. - PEI, X. J. \\ State Key Laboratory of Geohazard Prevention and Geoenvironment Protection, Chengdu \\ University of Technology, Chengdu-610059, China \\ (phone: +86-135-51029646; fax: +86-028-84078874) \\ *Corresponding author \\ e-mail:xuwenlai1983@163.com \\ (Received $3^{\text {rd }}$ Aug 2016; accepted $3^{\text {rd }}$ Oct 2016)
}

\begin{abstract}
The Constructed Rapid Infiltration System (CRIS) is widely applied for wastewater treatment. In China, however, fundamental research on functionality of CRIS is lacking. We used a CRIS simulation column to treat domestic sewage under experimental conditions, allowing determination of nitrogen pollutants removal performance. The obtained results showed that CRIS can effectively remove ammonia nitrogen with the average removal rate of $82.2 \%$ but results in a relatively low removal of total nitrogen (TN) with the average removal rate of $31.9 \%$. The reason is that the system is frequently subjected to alternation of drying and wetting, which allows effective aeration. This leads to aerobic conditions, which is incompatible with the anaerobic requirements of denitrifying bacteria. In addition, these bacteria likely lack a suitable carbon source, as organic matter is effectively removed in the upper (aerobic) layer of CRIS. Lastly, the filter material used is generally negatively charged, thus repels nitrate, which prevents its retention and results in its discharge with the outflow. As a net result, the TN removal rate is low.
\end{abstract}

Keywords: ammonia nitrogen; TN; nitrate nitrogen; organic matter; removal performance and mechanism

\section{Introduction}

The Constructed Rapid Infiltration System (CRIS) was developed for ecologicallyfriendly treatment of sewage and contaminated surface water, based on a rapid and simple infiltration system, by professor Zhong of China University of Geosciences (Xu et al., 2015; Xu et al., 2013). Since its development, it has been widely applied to wastewater treatment in domestic settings. The system is composed of a grille, a preliminary sedimentation basin, a high-permeability basin containing filter material and an outflow system. The high-permeability basin contains a fixed amount of artificial filter material, allowing to operate under alternating dry-wet conditions with a capacity of $1.0-1.5 \mathrm{~m}^{3} / \mathrm{m}^{2} \mathrm{~d}$ or $\mathrm{m} / \mathrm{d}$; the system is typically subjected to frequent flooding with intermittent dry periods (Xie et al., 2010). Wastewater is purified through adsorption, interception and decomposition of aquatic pollutants by microorganisms that are naturally present in the filter material of CRIS. The unique structure and dry-wet alternate inflow mode of CRIS result in a diverse microbial growth on the surface of the percolation medium, so that the medium usually supports both aerobic, anaerobic, and facultative anaerobic bacteria, all of which contribute to effective treatment of wastewater (Xu et al., 2011b; Liu, 2006). CRIS is preferably applied to treat domestic sewage from small towns as well as contaminated surface water. Removal of COD is typically about $85-90 \%$, ammonia nitrogen can be removed to over $90 \%$, and SS and LAS removal is achieved above 95\% (Jiang et al., 2011; Ma et al., 2008). With its convenient operation management and low investment and maintenance costs, CRIS is 
successfully promoted in many districts of China, with obvious benefits for the community, local economy and wildlife (Xu et al., 2011a; Liu, 2006). Nevertheless, at present most results on effectiveness are empiric, while basic and theoretical research is lacking. The research presented here was conducted to determine the efficiency and robustness of nitrogen removal by means of experiments performed using CRIS simulation columns processing domestic sewage. A theoretical interpretation of the biological processes at play is provided.

\section{Experimental materials and method}

\section{Experimental device}

A CRIS simulation column was constructed in the lab for research purposes. The main body of the reactor was composed of a hard PVC pipe of $200 \mathrm{~cm}$ high and an internal diameter of $20 \mathrm{~cm}$, the filter material consisted of $85 \%$ natural sand, $5 \%$ ferrous powder, 5\% marble sand and 5\% zeolite sand, and the height of the filter layer was 150 $\mathrm{cm}$. There was a sampling port every $0.25 \mathrm{~m}$ from top to bottom of the filter layer. Water was allowed to flow from top to bottom. A schematic of the experimental installation is shown in Fig.1.

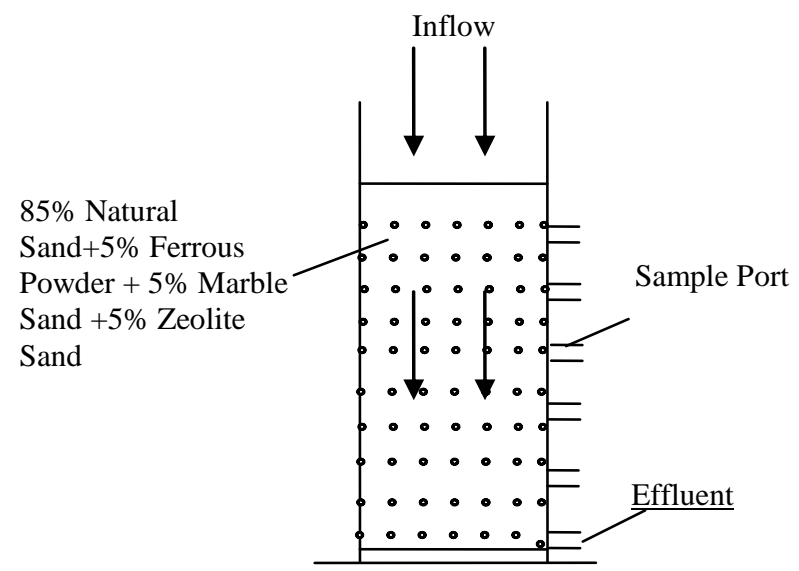

Figure 1. Experimental installation

\section{Monitoring Variables}

In order to resemble natural conditions, domestic wastewater was used as the experimental water sample, with quality indicators as shown in Table 1.

Table 1. Raw water quality indicators

\begin{tabular}{|c|c|c|c|c|c|c|}
\hline$\frac{\text { WaterTemperature }}{\left({ }^{\circ} \mathrm{C}\right)}$ & pH & $\begin{array}{c}\text { COD } \\
(\mathrm{mg} / \mathrm{L})\end{array}$ & $\underset{(\mathbf{m g} / \mathbf{L})}{\mathrm{SS}}$ & $\begin{array}{c}\text { TN } \\
(\mathrm{mg} / \mathrm{L})\end{array}$ & $\begin{array}{c}\mathbf{T P} \\
(\mathbf{m g} / \mathrm{L})\end{array}$ & $\begin{array}{r}\mathrm{NH}_{4}{ }^{+}-\mathbf{N} \\
(\mathrm{mg} / \mathrm{L})\end{array}$ \\
\hline $17-25$ & $7.00-8.10$ & $130-160$ & $30-60$ & $30-48$ & $0.90-1.80$ & $20-38$ \\
\hline
\end{tabular}

CRI was started up with raw wastewater. When the COD removal rate became stable, indicative of a successful and stable biofilm being formed, the CRIS analog column was fed with a hydraulic load of $1.00 \mathrm{~m}^{3} / \mathrm{m}^{2}$ per day. CRIS analog column was fed wastewater once every six hours and each feed lasted 20 minutes. To study nitrogen 
removal performance, the residual concentrations of nitrogen pollutants at various steps of the process were measured from water tapped from the sampling points and from the effluent once every two days. The experiment was performed from April 8, 2015 to June 30, 2015. The analytical methods used in the study are described in Methods of Water and Wastewater Monitoring and Analysis (edition 4) (Wang, 2002). The used tests determined $\mathrm{COD}_{\mathrm{Cr}}$ levels by the Potassium dichromate method, $\mathrm{NH}_{3}-\mathrm{N}$ by Nessler reagent colorimetry, $\mathrm{NO}_{3}-\mathrm{N}$ by ultraviolet (UV) spectroscopy and total nitrogen (TN) by alkaline potassium sulfate digestion followed by UV spectrophotometry. Since nitrogen in the form of nitrite was relatively low in the inflow water and was previously shown to be difficult to accumulate by CRIS (Liu, 2006), this variable was not determined.

\section{Results}

\section{Nitrogen Removal Principal of CRIS}

The CRIS took 14 cycles before outflow was stable. Once stability was achieved, the concentrations of nitrogen pollutants in the inflow and effluent of the experimental CRIS were determined as shown in Table 2. The average removal of nitrogen present in the form of ammonia was $82.2 \%$, while TN was removed with $31.9 \%$ efficiency on average. In contrast, concentrations of nitrogen in the form of nitrate increased from $2.4 \mathrm{mg} / \mathrm{L}$ in the inflow to $12.5 \mathrm{mg} / \mathrm{L}$ in the effluent (Table 2). These results were obtained with inflow water in which the ammonia concentration varied considerably, between $20.9 \mathrm{mg} / \mathrm{L}$ and $35.8 \mathrm{mg} / \mathrm{L}$. This variation was approximately halved in the effluent, suggesting that the system is highly resistant to variation in ammonia nitrogen input. The amplitude of variation in TN removal was relatively large. As a result, the concentrations of nitrate nitrogen and TN in the effluent varied considerably (Table 2).

Table 2. Inflow and effluent measurements

\begin{tabular}{|c|c|c|c|c|c|c|c|c|}
\hline \multirow[b]{2}{*}{ No. } & \multicolumn{3}{|c|}{ Ammonia Nitrogen } & \multicolumn{3}{|c|}{ Total Nitrogen } & \multicolumn{2}{|c|}{ Nitrate Nitrogen } \\
\hline & $\begin{array}{l}\text { inflow } \\
(\mathrm{mg} / \mathrm{L})\end{array}$ & $\begin{array}{c}\text { effluent } \\
(\mathrm{mg} / \mathrm{L})\end{array}$ & $\begin{array}{c}\text { removal } \\
(\%)\end{array}$ & $\begin{array}{l}\text { inflow } \\
(\mathrm{mg} / \mathrm{L})\end{array}$ & $\begin{array}{c}\text { effluent } \\
(\mathrm{mg} / \mathrm{L})\end{array}$ & $\begin{array}{c}\text { removal } \\
(\%)\end{array}$ & $\begin{array}{l}\text { inflow } \\
(\mathrm{mg} / \mathrm{L})\end{array}$ & $\begin{array}{l}\text { effluent } \\
(\mathrm{mg} / \mathrm{L})\end{array}$ \\
\hline 14 & $\begin{array}{c}31.2 \pm \\
1.1\end{array}$ & $\begin{array}{c}5.5 \pm \\
0.2\end{array}$ & 82.5 & $\begin{array}{c}43.6 \pm \\
1.9\end{array}$ & $\begin{array}{c}29.9 \pm \\
1.1\end{array}$ & 31.4 & $\begin{array}{r}2.3 \pm \\
0.09\end{array}$ & $\begin{array}{c}10.4 \pm \\
0.3\end{array}$ \\
\hline 15 & $\begin{array}{c}27.8 \pm \\
1.2\end{array}$ & $\begin{array}{c}4.9 \pm \\
0.2\end{array}$ & 82.4 & $\begin{array}{c}40.5 \pm \\
2.0\end{array}$ & $\begin{array}{c}27.5 \pm \\
1.2\end{array}$ & 32.2 & $\begin{array}{r}1.9 \pm \\
0.06\end{array}$ & $\begin{array}{c}12.1 \pm \\
0.5\end{array}$ \\
\hline 16 & $\begin{array}{c}32.5 \pm \\
1.6\end{array}$ & $\begin{array}{c}6.2 \pm \\
0.1\end{array}$ & 80.9 & $\begin{array}{c}42.9 \pm \\
1.8\end{array}$ & $\begin{array}{c}29.7 \pm \\
1.3\end{array}$ & 30.9 & $\begin{array}{r}2.4 \pm \\
0.11\end{array}$ & $\begin{array}{c}11.3 \pm \\
0.3\end{array}$ \\
\hline 17 & $\begin{array}{c}31.8 \pm \\
1.5\end{array}$ & $\begin{array}{c}4.1 \pm \\
0.2\end{array}$ & 87.1 & $\begin{array}{c}40.5 \pm \\
1.9\end{array}$ & $\begin{array}{c}29.9 \pm \\
1.4\end{array}$ & 33.7 & $\begin{array}{c}2.3 \pm \\
0.11\end{array}$ & $\begin{array}{c}12.6 \pm \\
0.4\end{array}$ \\
\hline 18 & $\begin{array}{c}33.6 \pm \\
1.6\end{array}$ & $\begin{array}{c}6.3 \pm \\
0.3\end{array}$ & 81.3 & $\begin{array}{c}43.8 \pm \\
2.1\end{array}$ & $\begin{array}{c}30.9 \pm \\
1.4\end{array}$ & 29.4 & $\begin{array}{r}2.4 \pm \\
0.11\end{array}$ & $\begin{array}{c}10.5 \pm \\
0.2\end{array}$ \\
\hline 19 & $\begin{array}{c}28.1 \pm \\
1.3\end{array}$ & $\begin{array}{c}5.5 \pm \\
0.2\end{array}$ & 80.6 & $\begin{array}{c}38.6 \pm \\
1.6\end{array}$ & $\begin{array}{c}28.7 \pm \\
1.1\end{array}$ & 33.5 & $\begin{array}{r}1.8 \pm \\
0.08\end{array}$ & $\begin{array}{c}13.4 \pm \\
0.3\end{array}$ \\
\hline 20 & $\begin{array}{c}23.9 \pm \\
1.0\end{array}$ & $\begin{array}{c}4.5 \pm \\
0.1\end{array}$ & 81.1 & $\begin{array}{c}34.2 \pm \\
1.2\end{array}$ & $\begin{array}{c}25.9 \pm \\
1.2\end{array}$ & 30.2 & $\begin{array}{r}2.3 \pm \\
0.03\end{array}$ & $\begin{array}{c}12.3 \pm \\
0.4\end{array}$ \\
\hline 21 & $\begin{array}{c}21.7 \pm \\
0.8\end{array}$ & $\begin{array}{c}4.2 \pm \\
0.2\end{array}$ & 80.5 & $\begin{array}{c}30.9 \pm \\
1.5\end{array}$ & $\begin{array}{c}23.3 \pm \\
1.0\end{array}$ & 27.8 & $\begin{array}{r}2.6 \pm \\
0.12\end{array}$ & $\begin{array}{c}12.5 \pm \\
0.1\end{array}$ \\
\hline 22 & $34.8 \pm$ & $6.2 \pm$ & 82.3 & $42.5 \pm$ & $27.0 \pm$ & 36.4 & $1.6 \pm$ & $13.5 \pm$ \\
\hline
\end{tabular}




\begin{tabular}{ccccccccc}
\hline & 1.2 & 0.1 & & 2.1 & 1.2 & & 0.05 & 0.1 \\
23 & $27.6 \pm$ & $4.6 \pm$ & 83.2 & $39.4 \pm$ & $27.1 \pm$ & 31.2 & $2.9 \pm$ & $12.4 \pm$ \\
& 1.2 & 0.2 & & 1.8 & 1.3 & & 0.13 & 0.5 \\
24 & $20.9 \pm$ & $3.8 \pm$ & 81.7 & $32.6 \pm$ & $23.3 \pm$ & 28.5 & $2.5 \pm$ & $11.6 \pm$ \\
& 0.6 & 0.1 & & 1.4 & 0.9 & & 0.10 & 0.1 \\
25 & $26.9 \pm$ & $4.7 \pm$ & 82.4 & $37.8 \pm$ & $26.3 \pm$ & 30.5 & $3.1 \pm$ & $14.4 \pm$ \\
& 1.1 & 0.2 & & 1.6 & 1.2 & & 0.15 & 0.2 \\
26 & $27.7 \pm$ & $5.2 \pm$ & 81.1 & $37.6 \pm$ & $27.7 \pm$ & 34.4 & $2.4 \pm$ & $13.7 \pm$ \\
& 1.3 & 0.2 & & 1.5 & 1.3 & & 0.10 & 0.2 \\
27 & $35.8 \pm$ & $6.7 \pm$ & 81.2 & $45.5 \pm$ & $30.6 \pm$ & 34.9 & $2.6 \pm$ & $13.3 \pm$ \\
& 1.5 & 0.3 & & 2.1 & 1.4 & & 0.11 & 0.4 \\
28 & $33.1 \pm$ & $5.8 \pm$ & 82.4 & $41.5 \pm$ & $28.6 \pm$ & 31.1 & $1.7 \pm$ & $12.8 \pm$ \\
& 1.6 & 0.2 & & 2.0 & 0.8 & & 0.04 & 0.1 \\
29 & $26.9 \pm$ & $4.8 \pm$ & 82.1 & $37.8 \pm$ & $26.2 \pm$ & 30.6 & $2.5 \pm$ & $12.2 \pm$ \\
& 0.9 & 0.1 & & 1.8 & 1.1 & & 0.10 & 0.1 \\
30 & $29.8 \pm$ & $5.9 \pm$ & 80.1 & $41.5 \pm$ & $28.4 \pm$ & 31.7 & $3.3 \pm$ & $13.8 \pm$ \\
& 1.3 & 0.2 & & 1.9 & 1.1 & & 0.15 & 0.3 \\
31 & $31.7 \pm$ & $5.6 \pm$ & 82.3 & $43.8 \pm$ & $28.4 \pm$ & 35.2 & $2.8 \pm$ & $11.9 \pm$ \\
& 1.5 & 0.2 & & 1.8 & 1.2 & & 0.13 & 0.1 \\
32 & $32.1 \pm$ & $4.6 \pm$ & 85.7 & $44.3 \pm$ & $29.5 \pm$ & 33.4 & $2.3 \pm$ & $13.0 \pm$ \\
Mean & 1.2 & 0.1 & & 2.1 & 1.3 & & 0.09 & 0.5 \\
value & 29.4 & 5.24 & 82.2 & 40.0 & 27.8 & 31.9 & 2.4 & 12.5 \\
\hline
\end{tabular}

Liu (2006) concluded that the top 100cm of CRIS typically represent an aerobic zone, while the $30 \mathrm{~cm}$ below this would be an anoxic zone. As can be seen from Table 3 and Figure 2, presenting findings from the individual sample points, the removal of ammonia nitrogen in the top section of CRIS $(0-25 \mathrm{~cm})$ was $9 \%$, increasing to $78 \%$ accumulatively when the water had penetrated $100 \mathrm{~cm}$, after which the removal of ammonia nitrogen levelled off to $84 \%$. The highest reduction increments were seen between $25 \mathrm{~cm}, 50 \mathrm{~cm}$ and $75 \mathrm{~cm}$. thus, most ammonia nitrogen is removed in the filtering between $25-75 \mathrm{~cm}$, not in the top $0-25 \mathrm{~cm}$. Possibly, the concentration of organic matter in the inflow promoted growth of heterotrophic bacteria, and this would inhibit the growth of nitrobacteria in the top layer of the filter (Hu et al., 2010). Related studies have shown that within a reactor there is competition for space to form biofilms as well as competition for dissolved oxygen among microorganisms, especially for the aerobic population (Hu et al., 2010). Nitrobacteria are chemo-autotrophs that, due to their lower growth rates, are generally outcompeted by heterotrophic bacteria. Moreover, dissolved oxygen will be abundant in the top layer of the column, where it is utilized by the surface biofilm consisting of heterotrophic bacteria residing there (Liu, 2006). By the time dissolved oxygen is diffused to where it can be utilized by nitrobacteria, its concentration would have decreased considerably, further limitating the reproduction of nitrobacteria (Xu et al., 2011a). Finally, in the early stage of inflow, most organic nitrogen was decomposed to ammonia nitrogen, which increased the concentration of ammonia nitrogen, further contributing to the low ammonia nitrogen removal in the top section of $0-25 \mathrm{~cm}$ of CRIS (Xu et al., 2011b).

Table 4 and Figure 2 lists the total nitrogen concentrations at individual sample points. As can be seen, TN removal in filtering layer $0-75 \mathrm{~cm}$ was $13.4 \%$ on average, decreasing to $11.4 \%(24.8 \%-13.4 \%)$ in the section $75-100 \mathrm{~cm}$ and to $6.5 \%(31.3 \%-24.8 \%)$ for the last $100-150 \mathrm{~cm}$. Nitrate nitrogen increased by $1.95 \mathrm{mg} / \mathrm{L}$ in the section $0-25 \mathrm{~cm}$, 
and by $3.99 \mathrm{mg} / \mathrm{L}$ in section $25-50 \mathrm{~cm}$, where it increased at the highest rate (Table 5 and Figure 2). After this, the increment dropped to $3.11 \mathrm{mg} / \mathrm{L}$ in layer $50-100 \mathrm{~cm}$, followed by marginal removal of $0.41 \mathrm{mg} / \mathrm{L}$ in layer $100-150 \mathrm{~cm}$. Since ammonia nitrogen was the main form of nitrogen in the inflow, the nitrate nitrogen concentration is comparatively low, so the ammonia nitrogen was nearly completely nitrificated in layer $0-100 \mathrm{~cm}$, which increased the nitrate nitrogen concentration in this section (Ma et al., 2009). Removal of ammonia nitrogen was high in the top $100 \mathrm{~cm}$ and low in the section 100$150 \mathrm{~cm}$, while nitrification occurring earlier had consumed most of the dissolved oxygen, resulting in inhibition of nitrification in layer $100-150 \mathrm{~cm}$. Instead, denitrification was promoted here by anaerobic bacteria. Taking together, nitrate nitrogen increased steadily in layer 100-150cm (Xu et al., 2011c).

Table 3. Ammonia nitrate concentrations at individual sample points

\begin{tabular}{cccccccc}
\hline \multirow{2}{*}{ No. } & \multicolumn{7}{c}{ Depth of CRIS Filtration Pool(cm) } \\
\cline { 2 - 7 } & 0 & 25 & 50 & 75 & 100 & 125 & 150 \\
\hline 43 & $30.5 \pm$ & $27.4 \pm$ & $19.3 \pm$ & $9.6 \pm 0.4$ & $6.1 \pm 0.3$ & $5.0 \pm 0.2$ & $4.3 \pm 0.2$ \\
& 1.2 & 1.1 & 0.9 & & & & \\
44 & $31.0 \pm$ & $27.9 \pm$ & $19.7 \pm$ & $10.2 \pm$ & $6.3 \pm 0.3$ & $5.5 \pm 0.1$ & $4.9 \pm 0.2$ \\
& 1.5 & 1.2 & 0.7 & 0.5 & & & \\
45 & $31.7 \pm$ & $28.2 \pm$ & $20.0 \pm$ & $10.7 \pm$ & $6.7 \pm 0.2$ & $5.8 \pm 0.2$ & $5.2 \pm 0.1$ \\
& 1.4 & 1.1 & 0.7 & 0.5 & & & \\
46 & $29.3 \pm$ & $27.4 \pm$ & $18.4 \pm$ & $9.2 \pm 0.3$ & $6.8 \pm 0.1$ & $5.4 \pm 0.1$ & $4.6 \pm 0.2$ \\
& 0.9 & 1.2 & 0.6 & & & & \\
& $32.6 \pm$ & $29.3 \pm$ & $19.8 \pm$ & $11.3 \pm$ & $7.3 \pm 0.3$ & $5.8 \pm 0.2$ & $5.2 \pm 0.1$ \\
Mean & 1.2 & 0.8 & 0.5 & 0.4 & & & \\
Concentration & 31.0 & 28.0 & 19.4 & 10.2 & 6.6 & 5.5 & 4.8 \\
Mean & & & & & & & \\
Removal(\%) & 0 & 9.6 & 37.3 & 67.1 & 78.6 & 82.3 & 84.4 \\
\hline
\end{tabular}

Table 4. Total nitrogen concentrations at individual sample points

\begin{tabular}{cccccccc}
\hline \multirow{2}{*}{ No. } & \multicolumn{7}{c}{ Depth of CRIS Filtration Pool(cm) } \\
\cline { 2 - 7 } & 0 & 25 & 50 & 75 & 100 & 125 & 150 \\
\hline 43 & $43.5 \pm$ & $41.9 \pm$ & $39.7 \pm$ & $37.6 \pm$ & $32.3 \pm$ & $30.5 \pm$ & $29.3 \pm$ \\
& 2.1 & 1.1 & 1.9 & 1.8 & 1.6 & 1.5 & 1.4 \\
44 & $42.0 \pm$ & $40.8 \pm$ & $38.8 \pm$ & $36.8 \pm$ & $32.5 \pm$ & $30.2 \pm$ & $29.6 \pm$ \\
& 2.0 & 0.7 & 1.8 & 1.8 & 1.6 & 1.2 & 1.4 \\
45 & $40.1 \pm$ & $38.5 \pm$ & $37.5 \pm$ & $35.7 \pm$ & $31.0 \pm$ & $29.8 \pm$ & $29.4 \pm$ \\
& 1.1 & 1.9 & 1.8 & 1.6 & 1.5 & 1.4 & 1.3 \\
46 & $45.2 \pm$ & $43.3 \pm$ & $42.0 \pm$ & $38.9 \pm$ & $33.4 \pm$ & $31.7 \pm$ & $28.5 \pm$ \\
& 2.0 & 1.7 & 2.0 & 1.7 & 1.6 & 1.2 & 1.2 \\
47 & $42.3 \pm$ & $40.7 \pm$ & $38.5 \pm$ & $35.5 \pm$ & $31.1 \pm$ & $29.9 \pm$ & $29.6 \pm$ \\
& 1.8 & 2.0 & 1.6 & 1.6 & 1.5 & 1.4 & 1.3 \\
Mean & 42.6 & 41.0 & 39.3 & 36.9 & 32.0 & 30.4 & 29.2 \\
Concentration & & & & & & & 31.3 \\
\hline Mean & 0 & 3.7 & 7.7 & 13.4 & 24.8 & 28.6 & \\
Removal(\%) & & & & & & & \\
\hline
\end{tabular}


Table 5. Nitrate nitrogen concentrations at individual sample points

\begin{tabular}{cccccccc}
\hline \multirow{2}{*}{ No. } & \multicolumn{7}{c}{ Depth of CRIS Filtration Pool(cm) } \\
\cline { 2 - 8 } & 0 & 25 & 50 & 75 & 100 & 125 & 150 \\
\hline 43 & $2.50 \pm$ & $5.74 \pm$ & $8.58 \pm$ & $10.07 \pm$ & $11.10 \pm$ & $11.68 \pm$ & $11.72 \pm$ \\
& 0.12 & 0.26 & 0.42 & 0.39 & 0.55 & 0.43 & 0.57 \\
44 & $2.20 \pm$ & $5.60 \pm$ & $8.82 \pm$ & $9.89 \pm$ & $11.95 \pm$ & $12.06 \pm$ & $12.12 \pm$ \\
& 0.09 & 0.25 & 0.41 & 0.47 & 0.57 & 0.60 & 0.60 \\
45 & $2.71 \pm$ & $5.93 \pm$ & $7.95 \pm$ & $9.62 \pm$ & $11.88 \pm$ & $12.09 \pm$ & $12.11 \pm$ \\
& 0.13 & 0.29 & 0.39 & 0.44 & 0.56 & 0.48 & 0.59 \\
46 & $3.15 \pm$ & $6.75 \pm$ & $8.89 \pm$ & $10.19 \pm$ & $12.38 \pm$ & $12.54 \pm$ & $12.97 \pm$ \\
& 0.28 & 0.33 & 0.27 & 0.48 & 0.55 & 0.52 & 0.61 \\
47 & $2.40 \pm$ & $6.12 \pm$ & $8.45 \pm$ & $9.95 \pm$ & $11.24 \pm$ & $11.66 \pm$ & $11.71 \pm$ \\
& 0.10 & 0.29 & 0.37 & 0.42 & 0.45 & 0.54 & 0.52 \\
Mean & 2.59 & 6.03 & 8.54 & 9.94 & 11.71 & 12.01 & 12.13 \\
Concentration & & & & & & & \\
\hline
\end{tabular}

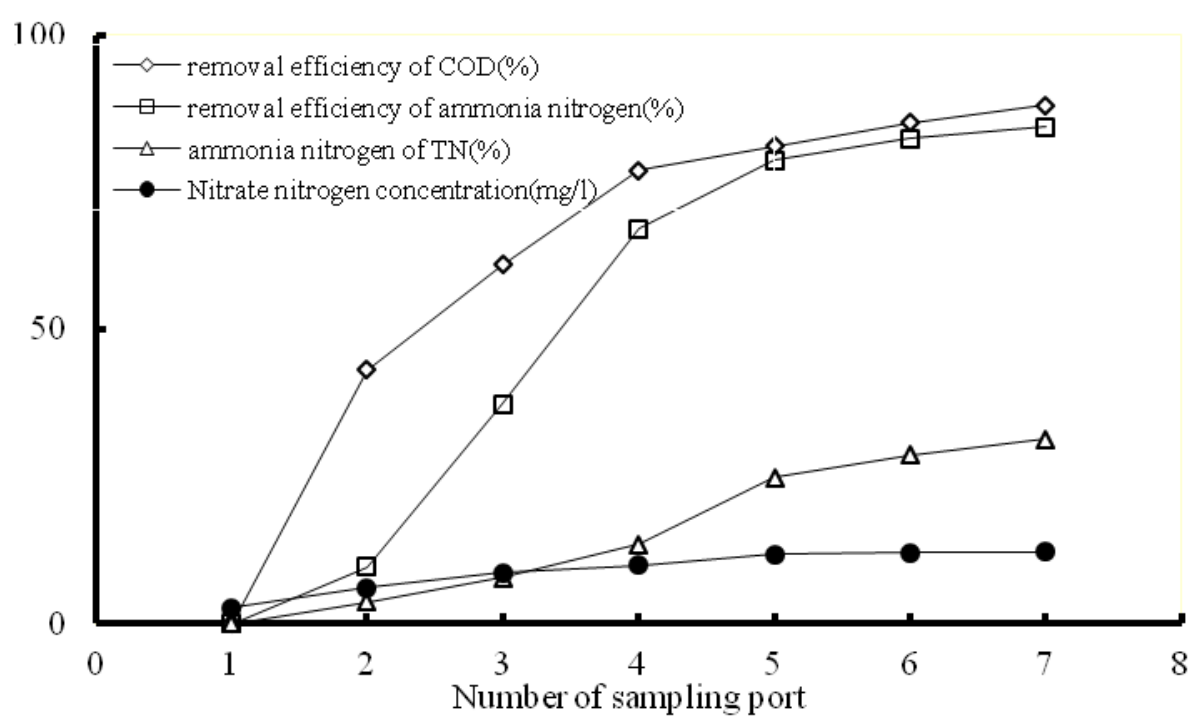

Figure 2. Pollutant concentration and the removal rates at individual sample points

\section{Denitrification Mechanism Analysis of CRIS}

Ammonia is mainly oxidized to nitrate by nitrosifying and nitrifying bacteria in CRIS (Zhao, 2010). It is first oxidized to nitrite by nitrosifying bacteria, which is then oxidized to nitrate nitrogen by nitrofying bacteria. The relative amounts and activities of nitrosifying and nitrifying bacteria affect the nitrofying process directly (Xu, 2011). Both populations depend on environmental factors for their survival such as $\mathrm{pH}$, temperature, absence of toxic and other harmful substances such as heavy metals and dissolved oxygen (Xu, 2011). The experiments described here modelled treatment of domestic sewage, which contains very low concentrations of heavy metals. During the experiment the room temperature varied between $20-30^{\circ} \mathrm{C}$, which is close to the optimal temperature for nitrification. The filtrate contained $10 \%$ marble sand that maintained the $\mathrm{pH}$ between 7.15 and 8.03, close to the optimal $\mathrm{pH}$ range for nitrification. We conclude that dissolved oxygen was the main factor affecting the nitrification in CRIS (Xu, 2011). 
The reason why TN removal was low in CRIS can be explained as follows. Ammonia nitrogen ions are positively charged and are absorbed by negatively-charged filter particles and microorganisms. The ions are transformed into nitrate by nitrifying bacteria under aerobic conditions, which can further be metabolized to gaseous nitrogen $\left(\mathrm{N}_{2}\right)$ under anaerobic conditions, resulting in nitrogen removal from the system (Xu, 2011). Table 5 shows that in filter chamber, the oncentration of nitrate nitrogen was above $12 \mathrm{mg} / \mathrm{L}$ in outflow, compared to approximately $2 \mathrm{mg} / \mathrm{L}$ in the inflow, which suggested that nitrification dominated denitrification. Denitrifying bacteria use nitrate nitrogen as electron acceptor and organic matter as donor to conduct anaerobic respiration, with the net result that nitrate nitrogen is reduced to gaseous nitrogen. Nitrate nitrogen denitrification can only be achieved under strict anaerobic conditions, provided there is enough organic carbon present (Xu, 2011; Yao, 2006).

CRIS is used under conditions where it is frequently flooded with intermittent dry periods, which results in efficient aeration. Since nitrate nitrogen concentration increased in CRIS (Table 5 and Figure 2), it can be concluded that aerobic conditions is applied, since denitrifying bacteria are strictly anaerobic. Nitrate nitrogen is not easily converted to nitrogen gas via denitrification. In deeper layers $(100-150 \mathrm{~cm})$ of the filter chamber, the concentration of dissolved oxygen was low, but organic matter had most likely been decomposed and removed in the layers above, since CRIS is effective for organic matter removal (Table 6 and Figure 2). As such, denitrification was most probably inhibited by lack of a suitable carbon source, and nitrate nitrogen couldn't be transformed into nitrogen gas to be removed. Nitrate nitrogen is negatively charged and dissolves well in water; therefore, it cannot be absorbed or retained by filter material or microorganisms. Instead, it maintains dissolved in the water and is removed with the outflow, resulting in a relatively high concentration of TN in the outflow of CRIS.

Table 6. COD concentrations at individual sample points

\begin{tabular}{lcccrrrr}
\hline & \multicolumn{7}{c}{ Depth of CRIS Filtration Pool(cm) } \\
\cline { 2 - 8 } & \multicolumn{1}{c}{0} & \multicolumn{1}{c}{25} & \multicolumn{1}{c}{50} & 75 & 100 & \multicolumn{1}{c}{125} & 150 \\
\hline Mean Concentration & 160.10 & 90.87 & 61.67 & 36.23 & 30.82 & 23.33 & 19.69 \\
Mean Removal(\%) & 0 & 43 & 61 & 77 & 81 & 85 & 88 \\
\hline
\end{tabular}

\section{Conclusions}

There are three reasons why removal of ammonia nitrogen but not of total nitrogen is effective in CRIS:

(1) The lack of anaerobic conditions: frequent dry periods intermitting flooding result in effective aeration, and that leads to operation under aerobic conditions, which cannot support denitrifying bacteria.

(2) The lack of organic matter: organic matter is almost completely removed in the upper layer of CRIS, further contributing to low denitrification efficiency as the denitrifying bacteria lack a carbon source.

(3) Filter material has the same charge as nitrate: both are negatively charged and nitrate nitrogen is highly soluble in water, which makes it difficult to retain nitrate in the filter material; instead it is discharged with the outflow resulting in a net low TN removal rate. 
Acknowledgements. The research was funded by the Natural Science Foundation of China (No. 41502333), the State Key Laboratory of Geohazard Prevention and Geoenvironment Protection Foundation (No.SKLGP2015Z012, SKLGP2014Z001), the specialized research fund for the doctoral program of colleges and universities (No.20135122120020), the scientific research plan of education department of Sichuan Province (No.14ZB0073).

\section{REFERENCES}

[1] Hu, B.W., Cheng, W., Han, Z. (2010): Experimental study on degradation law of organic matter and ammonia nitrogen in Biological Aerated Filter. - Shuili Xuebao 41(3):374-378.

[2] Jiang, X., Ma, M.C., Lu, A.H. (2011): Analysis of microbial molecular ecology techniques in Constructed Rapid Infiltration System. - Journal of Earth Science 22(5):669-676.

[3] Liu, J.B. (2006): Study on contaminant removal mechanism and efficiency of constructed rapid infiltration system, (Doctoral Dissertation). - China University of Geosciences, Beijing.

[4] Ma, L.M., Liu, C., Cui, C.Y. (2008): Optimizing operational parameter of constructed rapid infiltration system in urban wastewater treatment. - Technology of Water Treatment 34(6): 41-57.

[5] Ma, M.C., Li, J.M., Du, Y.P. (2009): Summarization of research and application in Constructed Rapid Infiltration System. - Environmental Engineering 27:74-77.

[6] Wang, X. (2002): Methods of Water and Wastewater Monitoring and Analysis (edition 4). - China Environmental Science Press, Beijing.

[7] Xie, Y., Kang, A., Li, M., He, J., Chen, H. (2010): Analysis of denitrification and distribution of microbial strain in three stages constructed rapid infiltration system. Chinese Journal of Environmental Engineering 4(6):1272-1275.

[8] Xu, W. (2011): Pollutant removal mechanism and dynamics in CRI system, (Doctoral Dissertation). - Southwest jiaotong university, Chengdu.

[9] Xu, W., Liu, G., Cui, G.Y., Luo, J. (2013): Relationship between microbiologic properties and short-cut nitrification and denitrification in Constructed Rapid Infiltration System. - Journal of Pure and Applied Microbiology 7(2):1227-1232.

[10] Xu, W., Yang, Y.N., Cheng, C., Pei, X.J., Luo, J.( 2015): Treat phoenix river water by Constructed Rapid Infiltration System. - Journal of Coastal Research 73S:386-390.

[11] Xu, W., Zhang, J., Liu, Y. (2011a): Organic matter degradation kinetics and filter layer height calculation model in constructed rapid infiltration system. - Fresenius environmental bulletin 20(6A):1487-1493.

[12] Xu, W., Zhang, J., Liu, Y. (2011b): Degradation of organic matter and ammonia nitrogen in Constructed Rapid Infiltration System. - Fresenius Environmental Bulletin 20(7):1685-1690.

[13] Xu,W., Zhang, J., Liu, Y. (2011c): $\mathrm{NH}_{3}-\mathrm{N}$ degradation dynamics and calculating model of filtration bed height in Constructed Soil Rapid Infiltration. - Chinese Geographical Science 21(6): 637-645.

[14] Yao, R. (2006): Construction of the Constructed Rapid Infiltration and its application study in Three-Gorges Reservoir Region, (Doctoral Dissertation). - Chongqing University, Chongqing.

[15] Zhao, F. (2010): Study on the technology of high concentration domestic sewage treatment by Ecology Constructed Rapid Infiltration System (ECRI), (Doctoral Dissertation). - China University of Geosciences, Beijing. 